\title{
ReCENZJA WYDAWNICZA KSIĘGI JUBILEUSZOWEJ \\ Profesora ZW. dR hab. StanisŁaWa Wójcika, Logos i ethos W Polityce
}

Recenzowana księga jubileuszowa poświęcona została wybitnemu uczonemu, który wiele znaczy w życiu naukowym naszego państwa. W ciągu blisko pięćdziesięciu lat, jakie upływają od ukończenia studiów na Wydziale Prawa i Administracji UMCS, prof. Stanisław Wójcik rozwinął działalność naukową i organizacyjną w skali, jaka rzadko bywa udziałem całych zespołów badawczych. Przy okazji pisania pracy magisterskiej (pod kierunkiem prof. zw. dr. hab. Jerzego Ignatowicza, wybitnego znawcy problematyki prawa cywilnego, spółdzielczego i rolnego) dał się poznać jako świetnie zapowiadający się prawnik. Wybór tematu i treść rozważań zadecydowała o dalszej jego drodze zawodowej, przesądzając o wyborze pracy naukowej. Los jednak sprawił, że nie znalazł on zatrudnienia w Katedrze Prawa Cywilnego uczelni, którą ukończył, lecz podjął działalność dydaktyczną i naukową w Instytucie Nauk Społeczno-Politycznych Akademii Rolniczej w Lublinie. Po reorganizacji Instytutu Nauk Politycznych został przyjęty do Międzyuczelnianego Instytutu Nauk Politycznych UMCS, który przekształcił się wkrótce w Wydział Politologii tejże uczelni. W tym okresie prof. Wójcik pozostawał pod przemożnym wpływem swojego mistrza naukowego prof. Ignatowicza, aczkolwiek z racji miejsca zatrudnienia jego badania zaczęły coraz bardziej oscylować w kierunku zagadnień dotyczących administracji publicznej i samorządu, początkowo pracowniczego, potem terytorialnego. Teksty pisane w tym czasie dowodzą niepośledniej wiedzy prawniczej, a obok niej politologicznej oraz socjologicznej. Efektem jego dociekań była praca doktorska Proces kształtowania się kolektywów pracowniczych w państwowych ośrodkach maszynowych obroniona na Wydziale Dziennikarstwa i Nauk Politycznych Uniwersytetu Warszawskiego 5 listopada 1980 r.

Po obronie pracy doktorskiej prof. Wójcik zmienił diametralnie obszar swoich dociekań naukowych, podejmując badania nad polską myślą gospodarczą i narodowo-państwową w okresie dwudziestolecia międzywojennego. Efektem tych zainteresowań była znakomita rozprawa $\mathrm{Na}$ ród i państwo w myśli społecznej II Rzeczypospolitej (Lublin 1987, ss. 143). 
Dzieło to z trudnością przebijało się do obiegu naukowego, gdyż burzyło ugruntowane stereotypy i mity, pozostając w faktycznej opozycji do utartych schematów marksistowskich. Kolejną książką jubilata była monografia Cechy narodowe Polaków w polemikach okresu międzywojennego (Lublin 1989, ss. 308). Przy jej konstruowaniu wyraźnie doszły do głosu zainteresowania filozoficzno-socjologiczne profesora. Pozostając w nurcie badań nad dziejami myśli polityczno-prawnej, w dalszych swoich dociekaniach jubilat zmierzał coraz wyraźniej w kierunku badań o charakterze społeczno-gospodarczych. Przedmiotem jego habilitacji przeprowadzonej 14 października 1996 r. na Wydziale Nauk Społecznych Uniwersytetu im. Adama Mickiewicza w Poznaniu stała się rozprawa Ekonomia społeczna wedtug koncepcji Stanistawa Grabskiego (Lublin 1995, ss. 349). Recenzentami w przewodzie habilitacyjnym byli m.in. prof. zw. dr hab. Czesław Strzeszewski, emerytowany już wówczas profesor KUL, i prof. zw. dr hab. Franciszek Ryszka z PAN. W dniu 24 marca 1997 r., po przeprowadzeniu przewodu habilitacyjnego, prof. Wójcik uzyskał stopień naukowy doktora habilitowanego nauk ekonomicznych w zakresie ekonomii, specjalność polityka gospodarcza.

Po uzyskaniu stopnia doktora habilitowanego, we wrześniu 1997 r. prof. Wójcik przeniósł się do Katolickiego Uniwersytetu Lubelskiego, podejmując pracę w Katedrze Politologii w Instytucie Socjologii. W 1999 r. został wybrany na stanowisko dyrektora Instytutu Socjologii KUL, którą to funkcję pełnił przez trzy kadencje do 2008 r., przygotowując Instytut do spełnienia standardów akredytacyjnych. W wyniku wytężonej pracy jubilata kierowany przez niego Instytut uzyskał w grudniu 2006 r. I kategorię KBN. Jednocześnie od 1 września 1999 r. kieruje Katedrą Samorządu Terytorialnego i Polityki Lokalnej. W 2009 r. prof. Wójcik został dyrektorem Instytutu Nauk Politycznych i Spraw Międzynarodowych KUL, którą to funkcję pełnił do $2016 \mathrm{r}$. W tym okresie zgromadził kadrę naukową, przygotował i przeprowadził wszystkie procedury niezbędne do utworzenia kierunku studiów Nauka o polityce. W roku akademickim 2013/2014 powołał nowy kierunek Bezpieczeństwo narodowe, a w następnym roku 2014/2015 wspierał działania na rzecz powołania kierunku Stosunki Międzynarodowe.

Mimo wytężonej pracy organizacyjnej jubilat znajdował czas i energię na pracę naukową. Po zatrudnieniu w Katolickim Uniwersytecie Lubelskim napisał wiele znaczących artykułów oraz monografii. Wspomnieć można w tym miejscu chociażby: Naród polski w publicystyce PRL 
(Wydawnictwo Naukowe KUL, Lublin 2002, ss. 231); Zapomniana polska ekonomia społeczna XX wieku (Towarzystwo Naukowe KUL, Lublin 2002, ss. 249); Naród, samorząd terytorialny, demokracja w III Rzeczypospolitej (Towarzystwo Naukowe KUL, Lublin 2007, ss. 281); Imperialne państwo rynkowe. Dynamika i bariery (Wydawnictwo KUL, Lublin 2010, ss. 194); Samorząd i państwo. Przyszłość i odpowiedzialność (Wydawnictwo KUL, Lublin 2013, ss. 139); Personalizm polityczny. Zarys problemów (Wydawnictwo KUL, Lublin 2015, ss. 164); Polskie drogi personalizmu społeczno-politycznego (Wydawnictwo KUL, Lublin 2018, ss. 213). W dorobku jubilata znalazło się 30 rozdziałów w monografiach, 41 artykułów oraz liczne hasła encyklopedyczne. Sporządził on także szereg recenzji wydawniczych.

Stanisław Wójcik to przede wszystkim zasłużony badacz, którego publikacje wniosły znaczący wkład we współczesną naukę o polityce i administracji, są szczególnie cenione przez badaczy samorządu terytorialnego i zawodowego. Do jego najważniejszych osiągnięć należą opracowanie historii polskiej myśli samorządowej oraz próby dookreślenia tożsamości nauki o polityce $\mathrm{w}$ nurcie systemu personalistycznego. W swoich tekstach ukazywał ułomności demokracji, samorządów, gospodarki rynkowej, wskazując przyczyny kryzysu obecnego państwa narodowego i formowanie się nowego typu państwa rynkowego, analizował ekonomiczne, polityczne i kulturowe wyzwania stojące przed państwem polskim, rodzące się nowe relacje między religią a państwem, rozważał miejsce współczesnego człowieka w polityce, domagając się przyznania mu niezbędnej suwerenności w gospodarowaniu swoim życiem społeczno-politycznym, omawiał problematykę wielokulturowości i ochrony tożsamości narodowej.

Jubilat jest uczonym ogłaszającym swoje wyniki badań $\mathrm{w}$ renomowanych periodykach, uczestnikiem licznych konferencji, na których jest oczekiwanym z niecierpliwością referentem. Wchodzi do historii nauki jako redaktor licznych prac zbiorowych, popularyzator wiedzy, inicjator i dusza przedsięwzięć zespołowych. Sukcesy badawcze prof. Wójci$\mathrm{ka}$, a nade wszystko ich tematyczne bogactwo, to nie tylko efekt talentu i pasji dociekania, ale $\mathrm{w}$ pierwszym rzędzie niezaprzeczalne umiejętności krytycznego spojrzenia na przedmiot badań. Teksty prof. Wójcika są dojrzałe warsztatowo i w niejednym przypadku posiadają charakter pionierski. Łączą analizę źródłową z teoretycznymi uogólnieniami. Autor śmiało przekracza tradycyjne podziały pielęgnowane przez tradycje akademickie, poruszając się z doskonałą znajomością rzeczy po polach licznych 
subdyscyplin nauk o polityce, a także administracji i samorządu. Podejmuje tematy ważne $\mathrm{i}$ istotne $\mathrm{w}$ dyskursie naukowym.

Jubilat to także znakomity, charyzmatyczny nauczyciel akademicki, którego wykłady odbywały się i wciąż jeszcze odbywają się w szczelnie wypełnionych salach, a seminaria przyciągają rzesze spragnionych rzetelnej wiedzy studentów. Wykształcił kilka pokoleń uczniów, którzy pod jego kierunkiem zdobyli ostrogi naukowe. Profesor Wójcik ma znaczące osiągnięcia na polu kształcenia kadr naukowych. Pod jego kierunkiem ponad 300 osób napisało prace licencjackie i magisterskie, był promotorem w 8 przewodach doktorskich, recenzował 15 prac doktorskich, 6 habilitacyjnych. Ponad to napisał 4 opinie w sprawie uzyskania stanowisk profesora nadzwyczajnego, 1 o tytuł profesora.

Za swoje osiągnięcia naukowe i dydaktycznejubilat otrzymał 5 Nagród Rektorskich, Srebrny Krzyż Zasługi (2007), Medal Władysława Grabskiego przyznany przez Rektora i Senat SGGW (2005), Medal Komisji Edukacji Narodowej (2002), Nagrodę Lubelskiego Angelusa (2009), Medal Caritas Polska (2010), Złoty Medal za Długoletnią Służbę w KUL (2012), Złoty Krzyż Zasługi (2018).

Krótkie przedstawienie drogi życiowej prof. Wójcika uzasadnia, że choćby tylko ze względu na wagę jego dokonań naukowych i organizacyjnych, sukcesy w zakresie kształcenia kadr naukowych, jak mało kto zasługuje on na uczczenie księgą jubileuszową. Z przedstawianych przez redaktorów materiałów wynika, że przygotowywana praca będzie dziełem nie tylko obszernym, ale o nieprzemijającej wartości naukowej. Niewątpliwie będą do jej treści sięgać przez wiele lat całe pokolenia badaczy. Tytuł księgi Logos i ethos w polityce jest wyjątkowo dobrze dobrany. Logos to słowo, lecz także termin oznaczający wewnętrzną racjonalność i uporządkowanie, ontologiczna zasada kosmosu, organizująca reguła, według której wszystko się urzeczywistnia, oraz prawo, które jest wspólne dla wszystkich rzeczy i wszystkimi rządzi, zawierając w sobie rozumność i inteligencję. Jest to wreszcie dobra argumentacja, odznaczająca się wewnętrzną spójnością i sensownością wypowiedzi. Z kolei ethos to przecież nic innego jak nośnik wartości, idei, które wpływają na procesy społeczne. Ethos to pewna zakorzeniona w społeczności całość. Ten łaciński tytuł książka chce połączyć z polityką. Tytuł zdaje się zwracać uwagę na współistnienie w polityce elementów logosu i ethosu. Wpisuje się to w planowaną treść tomu, podzielonego przez redaktorów na sześć odrębnych części, w ramach których zamieszczono kolejne teksty. Takiemu podziałowi 
opierającemu się na kryteriach przedmiotowych należy z przekonaniem przyklasnąć. Różni się on bardzo pozytywnie od przyjętego niekiedy w księgach jubileuszowych alfabetycznego uszykowania tekstów według nazwisk ich autorów. Taka koncepcja uchodzi nieraz za sprawiedliwą i słuszną, gdyż nikogo nie wyróżnia ani nie pomniejsza, chociaż nie jeden, być może, chętnie zmieniłby nazwisko z "Żyrzakiewicza” na „Abecedalskiego".

Oceniania księga jubileuszowa składa się - jak już wspomniano z sześciu części, noszących tytuły: O państwie i Kościele, O prawie i polityce społecznej, $O$ wartościach, $Z$ dziedziny samorzadu, Z komunikacji społecznej, wreszcie $Z$ dziedziny stosunków międzynarodowych. Autorami tekstów zamieszczonych $\mathrm{w}$ poszczególnych częściach są wybitni politologowie, teologowie, historycy, socjologowie, filozofowie, etycy, medioznawcy, wreszcie prawnicy, ekonomiści i znawcy stosunków międzynarodowych. Wśród autorów znaleźli się zarówno uczeni starszego pokolenia, już emerytowani lub powoli odchodzący od dydaktyki, liczni przedstawiciele młodszej generacji, która uzyskawszy tytuły naukowe profesorów bądź stopnie naukowe doktorów habilitowanych, przewodzi obecnie badaniom naukowym, kształtuje ich kierunki, wytycza nowe pola dociekań. Jest też wśród autorów wcale nie mała liczba bardzo obiecującej młodzieży naukowej, chociaż ujmując rzecz z punktu widzenia demograficznego, są to ludzie w średnim wieku, pokolenie trzydziesto i czterdziestolatków. Przy tak ogromnym i zróżnicowanym zbiorze tekstów nie sposób przedstawić chociażby w kilku słowach każdego z nich. Niżej podpisany nie czuje się zresztą upoważniony do oceny tak ogromnej i zróżnicowanej tematyki, jaka znalazła się w przygotowywanej księdze. Wśród 43 tekstów nie ma jednak takiego, który z racji wyboru tematu bądź ze względów metodologicznych czy jedynie formalnych nie kwalifikowałby się do publikacji. Wszystkie one dotyczą zagadnień ciekawych i interesujących, oparte są na istotnych źródłach i obszernej literaturze przedmiotu, prezentując doskonały warsztat badawczy ich autorów.

Wprawdzie trudno omawiać wszystkie teksty, ale wypada zwrócić uwagę chociażby tylko na nazwiska tych autorów, którzy zdecydowali się przeznaczyć swoje rozważania na uczczenie jubileuszu prof. Wójcika. Wśród piszących O państwie i Kościele znaleźli się przecież tacy koryfeusze nauki jak ks. prof. Stanisław Kowalczyk, ks. prof. Roman Dzwonkowski, ks. prof. Janusz Mariański czy ks. prof. Marek Wierzbicki. 
W części O prawie w polityce społecznej zamieścili swoje teksty m.in. prof. Jerzy Babiak, prof. Jacek Sobczak. Problem Wartości omawiali prof. Adam Gwiazda, prof. Anna Maria Marciniak, prof. Witold Wojdyło, prof. Piotr Kryczka. Samorządem zajęli się m.in. prof. Zbigniew Blok, prof. Robert Kmieciak, prof. Jacek Wojnicki. Zagadnieniom Komunikacji społecznej poświęcili uwagę prof. Janusz Włodzimierz Adamowski, prof. Roman Bäcker, prof. Ewa Maj. Teksty Z dziedziny stosunków międzynarodowych złożyli prof. Zdzisław W. Puślecki, prof. Marek Pietraś, prof. Andrzej Podraza.

Doniosłość zamieszczonych tekstów przemawia jednoznacznie za tym, aby znalazły się one, w miarę szybko, w obiegu naukowym. Gratulując redaktorom tomu zebrania tak wartościowych rozpraw, można jedynie stwierdzić, że dzięki ich pracy organizacyjnej świat naukowy będzie mógł zapoznać się z niezwykle ciekawym i powiązanym problemowo zbiorem tekstów. Wnoszą one istotny wkład w zakresie nauk społecznych i humanistycznych.

Mając na względzie walory poszczególnych tekstów, jak i całej proponowanej księgi, z pełnym przekonaniem opowiadam się za jej publikacją.

Witold Sobczak*

* Dr. hab. Witold Sobczak, prof. AJP, Zakład Administracji, Akademia im. Jakuba z Paradyża w Gorzowie Wielkopolskim, e-mail: wsobczak@ajp.edu.pl 